\title{
КАЧЕСТВА ЛИЧНОСТИ ПРЕДПРИНИМАТЕЛЯ КАК ОРИЕНТИР В ПОДГОТОВКЕ СТУДЕНТОВ К ПРЕДПРИНИМАТЕЛЬСКОЙ ДЕЯТЕЛЬНОСТИ
}

\author{
М.Т. Джумагулов \\ Московский гуманитарный университет
}

\begin{abstract}
Аннотация: В статье представлены интерпретации в научных публикациях терминов «предприниматель» и «предпринимательство», что позволило выделить характерные черты личности предпринимателя, в формировании которых важную роль играют преподаватели психолого-педагогических дисциилин.
\end{abstract}

Ключевые слова: предприниматель, предпринимательство, тип личности, качества личности

\section{UALITY OF THE ENTREPRENEUR'S PERSONALITY AS A REFERENCE POINT IN PREPARING STUDENTS FOR ENTREPRENEURSHIP}

\author{
M. T. Dzhumagulov \\ Moscow University for the Humanities
}

\begin{abstract}
The article presents the interpretation and interpretation of the terms «entrepreneur» and "entrepreneurship» in scientific publications, which allowed us to identify the characteristic features of the entrepreneur's personality, in the formation of which an important role is played by teachers of psychological and pedagogical disciplines.
\end{abstract}

Keywords: entrepreneur, entrepreneurship, personality type, personality qualities

За последние 30 лет тенденции, связанные с развитием рыночных отношений в Российской Федерации, привели к коренному изменению в обществе и социальноэкономических отношений, появлению нового типа личности и нового социального слоя - предпринимателей. Новые социально-экономические реалии выдвигают актуальные требования по разработке и реализации целевых учебных программ, направленных на подготовку студентов к предпринимательской деятельности.

Приступая к созданию таких программ, необходимо понимать кем, прежде всего для преподавателя, воспитателя, наставника является предприниматель? Какими личностными характеристиками он должен обладать, какому типу личности соответствовать и как, исходя из этого, выстраивать логику подготовки будущего предпринимателя.

Осознание конечной цели, исходящей из практических задач, требует учитывать, что определение данного типа личности должно дать педагогу образовательной организации чёткий ориентир, направление учебного процесса, нацеленного на формирование предпринимателя.

Самое раннее, ставшее впоследствии классическим, определение понятия «предприниматель», подразумевающее личность со специфическими чертами характера дал в «Эссе о природе торговли в общем плане» Р. Катильон - английский 
финансист (1680-1734 гг.). Рассматривая в своём труде теорию денежного обращения, Р. Катильон выделил в этом процессе определяющую роль предпринимателя, характеризуя его, как человека склонного к риску. Ту же характерную черту предпринимателя отмечал А. Смит в «Богатстве народов» (1776 г.), утверждая, что предприниматель получает прибыль в процессе своей деятельности как вознаграждение за то, что идёт на риск потери своего капитала (Смит 1993: 215).

Последователь учения А. Смита, Ж.Б. Сэй (1767-1831 гг.) в своём «Трактате по политической экономии», написанном в 1803 г. охарактеризовал предпринимателя как лицо, рискующее потерей средств ради организации выгодного для себя производства. (Сэй, 1986: 114)

Немецкий экономист, историк и социолог В. Зомбарт (1863-1941 гг.) считал предпринимателя человеком, наделённым особым предпринимательским духом, определяемым им как стремление к достатку, творчеству, жизни, насыщенной яркими событиям, проявляющим себя многогранной незаурядной личностью. (Зомбарт, 1994: 77)

Известный английский экономист основатель кейнсианского направления в экономике Дж. М. Кейнс (1883-1946 гг.) считал, что предприниматель не только склонен к риску, но и имеет особые качества, способные выявить оптимальное отношение между потреблением и сбережением. (Кейнс, 2013: 38)

Видный американский политолог и экономист Йозеф Шумпетер (18831950 гг.) в «Теории экономического развития» (1926 г.) выделяет у предпринимателя такую личностную черту как предрасположенность к новаторству. Он утверждал, что предпринимателем можно считать, лишь того, кто не связывает себя на длительное время с предприятием, а лишь использует его для подготовки реализации новых выгодных операций (Шумпетер, 1982: 142). Й. Шумпетер считал предпринимателя носителем таких определяющих качеств, как воля к победе, стремление к успеху, радость творчества (Шумпетер, 1982: 166).

Другой американский учёный П. Друкер (1909-2005 гг.) оценивал предпринимательство как важную общественную деятельность. В книге «Энциклопедия менеджмента» (2001 г.) он наделял предпринимателя такими характерными для него качествами, как новаторство, инновационность, лидерство (Друкер, 1992: 89).

Отечественные исследования в области определения сущности предпринимательства начались относительно недавно, в конце XX в., но даже за такой сравнительно непродолжительный период времени появился ряд интересных и заслуживающих внимания научных работ по данной тематике.

Так А. Бусыгин считает предпринимательство искусством и, прежде всего,- мыслительным процессом (Бусыгин, 2003: 13). Е.К. Завьялова и С.Т. Посохова в «Психологии предпринимательства» рассуждают о том, что предпринимателя отличает, прежде всего, активность, инициативность, самостоятельность, выраженные лидерские черты, способность к организации коммерческой деятельности (Завьялова, 2004: 1415, 20). С точки зрения В.А. Ситарова и А.И. Смирнова предприниматель - изобрета- 
тельный, крайне рациональный, меркантильный и практичный человек, вкладывающий свои ресурсы в то, из чего можно получить выгоду (Ситаров, 2006: 74).

А.Н. Асаул в работе «Оценка конкурентных позиций субъектов предпринимательской деятельности» отмечает, что инициативности для предпринимателя недостаточно, необходимо наличие определённого жизненного и предпринимательского опыта, а так же - знаний, умений и навыков. (Асаул, 2007: 42). М.Г. Лапуста и Ю.Л. Старостин считают предпринимателя хозяйственником, владельцем какой-либо собственности, способным идти на риск при воплощении идей в конкретные ресурсы, приносящие прибыль (Лапуста, 2008: 7). Н.В. Лежнёва, характеризует предпринимателя, как человека инициативного, нацеленного на получение прибыли, использующего новаторские идеи для улучшения процесса производства. (Лежнёва, 2012: 93).

В монографии Т.А. Волошиной, Н.Н. Шевченко, В.И. Шевченко для культивирования предпринимательских способностей рекомендуется особо обратить внимание на определённые характеристики данного типа личности, к которым можно отнести следующие: организационные, творческие, коммуникативные, управленческие (Волошина, 2013: 178).

В работе «Проблемы развития предпринимательских навыков при обучении менеджменту» А.П. Панфилова и С.М. Сычёва подчёркивают ещё ряд аспектов, характеризующих особенности личности предпринимателя, такие как: умение продавать, оценивать, видеть формирующиеся тенденции на рынке, которые могут принести выгоды (Панфилова, 2016: 10). С точки зрения А.П. Панфиловой и С.М. Сычёвой предприниматель рационально использует ресурсы для организации производства, при необходимости идёт на обоснованный риск, внедряет новые технологии и последовательно, действует в условиях возможной неопределённости (Панфилова, 2016: 11).

Одно из наиболее интересных определений предприимчивости, как равноценного определения предпринимательства и определённого морально нравственного психотипа даёт в «Энциклопедическом словаре педагога» В.С. Безрукова. Оно отличается от других аналогичных определений прежде всего тем, что в качестве обязательных особенностей предпринимателя выделены общечеловеческие ценностные и этические характеристики. По мнению В.С. Безруковой предприниматель это - волевая личность, умеющая оперативно принимать решения и действовать. Отличительными чертами предпринимателя В.С. Безрукова считает: уверенность, рациональность, сообразительность, активность, самостоятельность, ответственность, готовность идти на риск. Особо при этом подчёркивается обязательное нравственное начало, которое крайне важно для современного предпринимателя (Безрукова: 2000, 617).

Из проведённого исследования видно, что со временем определение «предприниматель», не теряя своей основной содержательной составляющей, трансформировалось, обогащаясь новыми содержательными смысловыми единицами, зависящими не только от взглядов и сферы деятельности эксперта, но также от времени и мировоззренческой базы общества, в котором оно употреблялось (таблицу 1 см на с.36). 


\section{Основные качества предпринимателя}

\begin{tabular}{|c|c|}
\hline Автор & редприниматель - это человек. . \\
\hline $\begin{array}{l}\text { Р. Катильон } \\
(1755 \text { г.) }\end{array}$ & $\begin{array}{l}\text { клонный к риску, посредник, связующее звено между производителя- } \\
\text { й и потребителями }\end{array}$ \\
\hline $\begin{array}{l}\text { А. Смит } \\
(1776 \text { г.) }\end{array}$ & $\begin{array}{l}\text { олучающий прибыль в процессе своей деятельности, как вознаграж- } \\
\text { ение за то, что идёт на риск потери своего капитала }\end{array}$ \\
\hline $\begin{array}{l}\text { Ж.Б. Сэй } \\
(1803 \text { г.) }\end{array}$ & $\begin{array}{l}\text { идущий на риск потери средств ради организации выгодного для себя } \\
\text { производства }\end{array}$ \\
\hline $\begin{array}{l}\text { В. Зомбарт } \\
(1913 \text { г.) }\end{array}$ & $\begin{array}{l}\text { имеющий предпринимательский дух, жажду денег, страсть к приклю- } \\
\text { чениям, изобретательность, расчётливость, старательность, умеющий } \\
\text { влиять на людей }\end{array}$ \\
\hline $\begin{array}{l}\text { Й. Шумпетер } \\
(1926 \text { г.) }\end{array}$ & $\begin{array}{l}\text { носитель таких обязательных для него качеств, как воля к победе, } \\
\text { стремление к успеху, радость творчества }\end{array}$ \\
\hline $\begin{array}{l}\text { Дж. М. Кейнс } \\
(1936 \text { г.) }\end{array}$ & $\begin{array}{l}\text { способный понять оптимальное отношение между потреблением и сбе- } \\
\text { режением, склонный к риску }\end{array}$ \\
\hline П. Друкер (2001 г.) & новатор и лидер \\
\hline $\begin{array}{l}\text { В.С. Безрукова } \\
(2000 \text { г.) }\end{array}$ & $\begin{array}{l}\text { волевой, умеющий оперативно принимать решения и действовать, уве- } \\
\text { ренный, рациональный, сообразительный, активный, ответственный, } \\
\text { готовый идти на риск. }\end{array}$ \\
\hline $\begin{array}{l}\text { А. Бусыгин } \\
\text { (2003 г.) }\end{array}$ & $\begin{array}{l}\text { активный, умеющий организовать собственное дело, нацеленный на } \\
\text { получение прибыли }\end{array}$ \\
\hline $\begin{array}{l}\text { Е.К. Завьялова, } \\
\text { С.Т. Посохова } \\
(2004 \text { г.) }\end{array}$ & $\begin{array}{l}\text { активный, инициативный, умеющий управлять людьми, предприимчи- } \\
\text { вый, способный организовать предпринимательскую деятельность }\end{array}$ \\
\hline $\begin{array}{l}\text { В.А. Ситаров, } \\
\text { А.И. Смирнов } \\
(2006 \text { г.) }\end{array}$ & $\begin{array}{l}\text { воплощающий рациональность, направленность на создание чего-то } \\
\text { нового с целью получения максимальной выгоды }\end{array}$ \\
\hline $\begin{array}{l}\text { М.Г. Лапуста, } \\
\text { Ю.Л.Старостин } \\
(2008 \text { г.) }\end{array}$ & $\begin{array}{l}\text { хозяйственник, владелец какой-либо собственности, способный идти } \\
\text { на риск при воплощении идей в конкретные ресурсы, приносящие при- } \\
\text { быль }\end{array}$ \\
\hline $\begin{array}{l}\text { Н.А. Некрасова } \\
(2012 \text { г.) }\end{array}$ & $\begin{array}{l}\text { ацеленный на доход, получаемый за счёт своей активности и инова- } \\
\text { ионности }\end{array}$ \\
\hline $\begin{array}{l}\text { Т.А.Волошина, } \\
\text { Н.Н.Шевченко, } \\
\text { В.И.Шевченко } \\
(2013 \text { г.) }\end{array}$ & $\begin{array}{l}\text { имеющий следующие качества: организационные, творческие, комму- } \\
\text { никативные, управленческие }\end{array}$ \\
\hline $\begin{array}{l}\text { А.П.Панфилова, } \\
\text { С.М.Сычёва } \\
(2016 \text { г.) } \\
\end{array}$ & $\begin{array}{l}\text { умеющий продавать, оценивать, видеть формирующиеся тенденции на } \\
\text { рынке, которые могут принести выгоды }\end{array}$ \\
\hline $\begin{array}{l}\text { В.А. Сидоров, } \\
\text { Е.Л. Кузнецова, } \\
\text { А.В. Болик } \\
(2017 \text { г.) } \\
\end{array}$ & $\begin{array}{l}\text { обладатель следующих качеств: эффективность, последовательность, } \\
\text { умение оптимально распределять ресурсы при построении предприя- } \\
\text { тия, способный к продуманному риску и действиям в условиях неопре- } \\
\text { делённости, новатор }\end{array}$ \\
\hline
\end{tabular}


Из таблицы видно, что большинство исследователей в данной области характеризуют предпринимателя как носителя совершенно конкретных и определённых установок, обладающего специфическим набором психологических черт, в совокупности формирующих уникальный тип личности:

- рискованность (Р. Катильон, А. Смит, Ж.Б. Сэй, Дж. Кейнс, М.Г. Лапуста, Ю.Л. Старостин, Н.А. Некрасова, Т.А. Волошина, Н.Н. Шевченко, В.И. Шевченко, В.А. Сидоров, Е.Л. Кузнецова, А.В. Болик);

- расчётливость/рациональность/практичность (Ж.Б. Сэй, Дж. Кейнс, В.А. Ситаров, А.И. Смирнов, М.Г. Лапуста, Ю.Л. Старостин, А.П. Панфилова, С.М. Сычёва, В.А. Сидоров, Е.Л. Кузнецова, А.В. Болик, В.С. Безрукова); - стремление к богатству (Ж.Б. Сэй, В. Зомбарт, В.А. Ситаров, А.И.Смирнов, Н.А. Некрасова, А.П. Панфилова, С.М. Сычёва);

- изобретательность/новаторство/инновачионность/креативность (В. Зомбарт, Й. Шумпетер, П. Друкер, А. Бусыгин, В.А. Ситаров, А.И. Смирнов, М.Г. Лапуста, Ю.Л. Старостин, Н.А. Некрасова, Т.А. Волошина, Н.Н. Шевченко, В.И. Шевченко, В.А. Сидоров, Е.Л. Кузнецова, А.В. Болик, В.С. Безрукова);

- активность/инициативность/предприимчивость (Е.К. Завьялова, С.Т. Посохова, Н.А. Некрасова, Т.А. Волошина, Н.Н. Шевченко, В.И. Шевченко, В.С. Безрукова);

- самостоятельность (Е.К. Завьялова, С.Т. Посохова, В.С. Безрукова);

- лидерство/организаторские способности (Е.К. Завьялова, С.Т. Посохова, Т.А. Волошина, Н.Н. Шевченко, В.И. Шевченко, В.А. Сидоров, Е.Л. Кузнецова, А.В. Болик);

- ориентация на практические результаты (М.Г. Лапуста, Ю.Л. Старостин);

- решительность/уверенность (Т.А. Волошина, Н.Н. Шевченко, В.И. Шевченко, В.С. Безрукова);

- контактность/общительность/ (Т.А. Волошина, Н.Н. Шевченко, В.И. Шевченко), презентабельность (Т.А. Волошина, Н.Н. Шевченко, В.И. Шевченко).

Развития этих качеств личности студента способно обеспечить:

- нацеленность на успех в предпринимательской деятельности, под которым понимается получение прибыли, дохода, достатка для удовлетворения своих потребностей;

- сформированность умения действовать в ситуациях, связанных с риском, и проявления в них умения избегать неудачи;

- обладание способностью субъективного контроля над разнообразными ситуациями в предпринимательской деятельности;

- проявление нравственных ценностей в предпринимательстве.

Выделив характерные черты личности предпринимателя, можно сделать следующий вывод: они должны выступать в качестве ориентира в подготовке студентов к предпринимательской деятельности. 


\section{СПИСОК ЛИТЕРАТУРЫ}

Асаул, А.Н. (2007) Оценка конкурентных позиций субъектов предпринимательской деятельности. - СПб. $271 \mathrm{c}$.

Безрукова, В.С. (2000) Основы духовной культуры (энциклопедический словарь педагога). - Екатеринбург. 937 с.

Бусыгин, А.В. (2003) Предпринимательство. - М: Прометей. 610 с.

Волошина, Т.А. (2013) Формирование предпринимательских качеств студентов педагогического вуза в процессе интерактивного обучения: монография // Т.А. Волошина, Н.Н. Шевченко, В.И. Шевченко. Петрозаводск: Verso, 222 с.

Друкер П.Ф. (1992) Рынок: как выйти в лидеры. Практика и принципы. М., $352 \mathrm{c}$.

Завьялова, Е.К., Посохова, С. Т. (2004) Психология предпринимательства. СПб., 295 с.

Зомбарт, В. (1994) Буржуа. Этюды по истории духовного развития современного экономического человека. М.: Наука, 443 с.

Кейнс, Дж. М. (2013) Общая теория занятости, процента и денег. М.: Бизнеском, 408 с.

Лапуста, М.Г., Старостин, Ю.Л. (2008) Предпринимательство. - М: Инфра-М, $608 \mathrm{c}$.

Лежнёва, Н.В. (2012) «Предпринимательство» как психолого-педагогическое понятие //Вестник КГУ им. Н.А. Некрасова (Кострома). Т. 18. С. 90-93.

Панфилова, А.П., Сычёва, С.М. (2016) Проблемы развития предпринимательских навыков при обучении менеджменту //Высшее образование сегодня. № 2. C. 7-11.

Сидоров, В.А., Кузнецова, Е.Л., Болик, А.В. (2017) Общая экономическая теория: учебник для студентов высших учебных заведений. Майкоп: ЭлИТ, 603 с.

Ситаров, В.А., Смирнов, А.И. Культура предпринимательства: теория и практика // М.: МосГУ; Вологда: Вологод. ин-т бизнеса, Полиграфист, 2006., 608 с.

Сэй Ж.- Б. (1986) Трактат политической экономии. М.: Мысль, 480 с.

Смит А. (1993) Исследования о природе и причинах богатства народов. 1 - 2кн. Антология экономической классики. - М.: Эконов, Т.1., 474 с.

Шумпетер, Й.А. (1982) Теория экономического развития: Исследование предпринимательской прибыли, капитала, кредита, процента и цикла конъюнктуры. M., C. 63.

Джумагулов Марк Тукенович - обучающийся 2 курса образовательной программы магистратуры по направлению подготовки 44.04.02 Психолого-педагогическое образование Московского гуманитарного университета. Научный руководитель - д.П.н., проф. Юсупов В.З. Адрес: 111395, Россия, г. Москва, ул. Юности, д. 5. Тел.: +7 (499) 374-74-59. Эл. адрес: kafedra@mosgu.ru 
Dzhumagulov Mark Tukenovich - is a 2-year student of the master's degree program in the field of training 44.04.02 Psychological and pedagogical education of the Moscow University for the Humanities. Scientific supervisor-doctor of science, prof. Yusupov V.Z. Postal address: 5 Yunosti str., Moscow, Russian Federation 111395. Tel.: +7 (499) 374-74-59. E-mail: kafedra@mosgu.ru

\section{Для цитирования:}

Джумагулов М.Т. Качества личности предпринимателя как ориентир в подготовке студентов к предпринимательской деятельности // Научные труды Московского гуманитарного университета. 2020. №4. C. 35-41. DOI: https://www.doi.org/10.17805/trudy.2020.4.5 